\title{
PEMANFAATAN MEDIA SISTEM INFORMASI GEOGRAFIS (SIG) UNTUK MENINGKATKAN MOTIVASI DAN HASIL BELAJAR SISWA MATA PELAJARAN IPS
}

\author{
I Wayan Witama ${ }^{1}$, I Gede Astra Wesnawa ${ }^{2}$, I Putu Sriartha ${ }^{3}$ \\ Program Studi Ilmu Pengetahuan Sosial, Universitas Pendidikan Ganesha Singaraja, Indonesia \\ e-mail:iwayanwitama69@gmail.com ${ }^{1}$,gedeastrawesnawa@yahoo.co.id², putusriartha@gmail.com ${ }^{3}$
}

\begin{abstract}
Abstrak
Penelitian ini dilaksanakan di SMP Negeri 1 Selemadeg dengan tujuan: (1) mengkaji motivasi belajar siswa dengan menggunakan aplikasi SIG sebagai media pembelajaran. (2) menganalisis hasil belajar siswa dengan menggunakan aplikasi SIG sebagai media pembelajaran. Untuk mencapai tujuan penelitian digu nakan rancangan eksperimen semu The Posttest-Only Control Group Design dengan menetapkan sampel dua kelas sebagai sampel kelas control dan kelas treatment yang telah disetarakan sebelumnya. Data motivasi dikumpulkan dengan kuesioner skala 5 dan data hasil belajar dikumpulkan dengan memberikan tes hasil belajar. Data yang diperoleh dianalisis dengan menggunakan statistik deskriptif dan statistik t-test. Hasil analisis data menunjukkan bahwa: (1) terdapat perbedaan yang signifikan motivasi belajar siswa yang menggunakan media SIG dengan menggunakan media light projector ( $\mathrm{t}$ hitung $=9,209$, $P<0,05$ ). Motivasi belajar siswa dengan pemanfaatan media SIG lebih tinggi (rata -rata $=$ 85,6 ) dibandingkan dengan pemanfaatan media light projector (rata-rata $=74,8$ ). (2) terdapat perbedaan yang signifikan hasil belajar siswa yang menggunakan media SIG dengan menggunakan media light projector ( $t$ hitung $=3,992, P<0,05)$. Hasil belajar siswa dengan pemanfaatan media SIG lebih tinggi $($ rata-rata $=11,9)$ dibandingkan dengan pemanfaatan media light projector (rata-rata $=8,3$ ). Implikasi hasil penelitian adalah penggunaan media SIG dapat dipertimbangkan untuk diimplementasikan dalam proses pembelajaran IPS di SMP terutama dalam meningkatkan motivasi dan hasil belajar siswa.
\end{abstract}

Kata kunci : Motivasi, Hasil belajar IPS, Media Sistem Informasi Geografis (SIG

\section{Abstrac}

This study was conducted at SMP Negeri 1 Selemadeg with purposes as follows: (1) to study the student learning motivation by using GIS application as learning media. (2) to analyze the student learning outcomes by using GIS applications as learning media. In order to achieve the research objectives by using design of study was the Posttest-Only Control Group Design by specifying two class samples as a control class sample and treatment class that they has been equivalented beforehand. Motivation data were collected with a 5-scale questionnaire and learning outcomes was collected by providing a learning outcome test. The data was obtained analyzed by using descriptive statistics and t-test statistics. The result of data analysis shows that: (1) there is a significant difference of students' learning motivation by using GIS media with light projector media ( $t$ count $=9,209, P<0,05)$. Student learning motivation with GIS media utilization is higher ( mean $=85,6)$ compared to light media projector (mean $=74,8)$. (2) there is a significant difference between student learning result by using GIS media with using light projector media ( $t$ count $=3$,992, $P<0,05$ ). Student learning outcomes with GIS media utilization (mean $=11,9)$ higher than with light projector media (mean $=8,3)$. Implication of res earch result is GIS media usage can be considered to be implemented in learning process of IPS in junior high, especially in improving motivation and result of student learning.

Keywords : Motivation, IPS learning result, Media of Geographic Information System (GIS). 


\section{PENDAHULUAN}

Upaya penataan pendidikan yang baik diharapkan agar bisa mengangkat harkat dan martabat suatu bangsa. Jadi pendidikan merupakan salah satu hal yang terpenting dalam kehidupan berbangsa dan bernegara. Maju mundurnya suatu bangsa dan negara sebagian besar ditentukan oleh maju mundurnya pendidikan di negara tersebut. Begitu pentingnya peran dan tujuan pendidikan maka mutu pendidikan haruslah ditingkatkan. Salah satu upaya untuk meningkatkan mutu pendidikan adalah melalui peningkatan kualitas pembelajaran, menyediakan tenaga pengajar yang profesional. Faktor guru memegang peranan yang sangat penting dalam proses pembelajaran. Tugas dan peranan guru antara lain adalah menggunakan strategi belajar mengajar yang cocok dan sesuai dengan materi pokok yang disampaikan. Selain itu guru sebagai "jantung" proses pembelajaran harus disiapkan supaya memiliki kemampuan dan kreativitas mengembangkan konten media pembelajaran yang menarik. Tanpa media pembelajaran yang tepat dan menarik maka proses komunikasi dan interaksi tidak akan berjalan efektif.

Media adalah sebuah alat yang mempunyai fungsi menyampaikan pesan (Bovee, 1997). Menurut Gerlach \& Ely (dalam Arsyad, 2007), mengatakan bahwa media apabila dipahami secara garis besar adalah manusia, materi, atau kejadian yang membangun kondisi yang membuat siswa mampu memperoleh pengetahuan, keterampilan atau sikap. Dalam pengertian ini guru, buku teks, dan lingkungan sekolah merupakan media. Secara lebih khusus pengertian media dalam proses belajar mengajar cendrung diartikan sebagai alat-alat grafis, photografis, atau elektronis untuk menangkap, memproses, dan menyusun kembali informasi visual atau verbal. Dari pendapat di atas dapat disimpulkan bahwa media merupakan alat bantu yang dapat digunakan sebagai perantara untuk menyampaikan pesan yang telah direncanakan oleh penyaji dalam hal ini guru kepada peserta didik sehingga apa yang menjadi tujuan pembelajaran dapat tercapai. Menurut (Arsyad, 2007:15) dalam proses belajar mengajar, dua unsur yang amat penting adalah metode mengajar dan media pembelajaran. Kedua aspek ini sangat berkaitan. Pemilihan salah satu metode mengajar tertentu akan mempengaruhi jenis media pembelajaran yang sesuai, meskipun masih ada berbagai aspek yang lain yang harus diperhatikan dalam memilih media antara lain tujuan pembelajaran, jenis tugas dan respon yang diharapkan siswa kuasai setelah pembelajaran berlangsung, dan konteks pembelajaran termasuk karakteristik siswa. Meskipun demikian dapat dikatakan bahwa salah satu fungsi utama media pembelajaran adalah sebagai alat bantu mengajar yang turut mempengaruhi iklim, kondisi, dan lingkungan belajar yang ditata dan diciptakan oleh guru. Hamalik (dalam Arsyad,2007:15-16) mengemukakan bahwa pemakaian media pembelajaran dalam proses belajar mengajar dapat membangkitkan keinginan dan minat yang baru, membangkitkan motivasi dan rangsangan kegiatan belajar, dan bahkan membawa pengaruh-pengaruh psikologis terhadap siswa.

Aplikasi Sistem Informasi Geografis (SIG) sebagai media pembelajaran IPS akan sangat membantu guru dalam proses belajar mengajar dan dapat dijadikan alat bantu dalam mencapai tujuan pembelajaran IPS sesuai dengan kurikulum. Aplikasi SIG diharapkan dapat memacu motivasi dan hasil belajar siswa dengan kondisi dinamis, kreatif dan relevan dengan kehidupan sehari-hari. Namun aplikasi SIG ternyata belum dimanfaatkan oleh guru secara maksimal. 
Burrough (1986) mendefinisikan SIG sebagai sistem berbasis komputer yang digunakan untuk memasukkan, menyimpan, mengelola, menganalisis dan mengaktifkan kembali data yang mempunyai referensi keruangan untuk berbagai tujuan yang berkaitan dengan pemetaan dan perencanaan. Komponen utama Sistem Informasi Geografis (SIG) dapat dibagi kedalam empat komponen utama yaitu: perangkat keras (digitizer, scanner, Central Procesing Unit (CPU), harddisk, dan lain-lain), perangkat lunak, organisasi (manajemen) dan pemakai (user).

Permasalahan empirik dalam pembelajaran IPS yang berlangsung di negara kita dewasa ini masih banyak menggunakan pendekatan yang menekankan pada pembelajaran konvensional dengan ceramah sehingga kurang mampu merangsang siswa untuk terlibat secara aktif dalam proses belajar mengajar (Suwarma,1991). Suasana belajar seperti ini semakin menjauhi peran pembelajaran IPS dalam upaya mempersiapkan warga negara yang baik dan mampu bermasyarakat (Kosasih, 1994).

Berdasarkan analisis terhadap kondisi pembelajaran IPS di SMP Negeri 1 Selemadeg bila dikaitkan dengan kajian teori, tujuan, esensi, dan peran kritis yang diemban oleh pembelajaran IPS, nampaknya persoalan tersebut memerlukan suatu alternatif pemecahan yang sangat mendesak untuk menjembatani persoalan-persoalan seputar proses pembelajaran IPS di SMP Negeri 1 Selemadeg. Dari hasil observasi yang dilakukan bahwa siswa kurang memiliki keinginan dan merasa kurang bersemangat mengikuti pelajaran IPS. Proses pembelajaran duduk, dengar, catat, diskusi dan presentasi merupakan hal yang sudah biasa dalam proses pembelajaran sehingga menyebabkan kejenuhan dikalangan siswa. Pengguanan media pembelajaran masih kurang karena sarana dan prasarana kurang memadai. Keadaan seperti ini mengakibatkan penurunan motivasi siswa untuk belajar IPS. Menurut Suhana (2014:24), Motivasi adalah merupakan kekuatan (power motivation, daya pendorong (driving forces), atau alat pembangun kesediaan dan keinginan yang kuat dalam diri peserta didik untuk belajar secara aktif, kreatif, efektif, inovat if dan menyenangkan dalam rangka perubahan prilaku baik dalam aspek kognitif, afektif dan psikomotorik. Fungsi motivasi merupakan alat pendorong terjadinya prilaku belajar peserta didik. Motivasi merupakan alat untuk mempengaruhi prestasi belajar peserta didik. Motivasi merupakan alat untuk memberikan direksi terhadap pencapaian tujuan pembelajaran. Motivasi merupakan alat untuk membangun sistem pembelajaran lebih bermakna. Hamalik (dalam Aunurrahman, 2016) mengemukakan bahwa motivasi adalah suatu perubahan energi di dalam pribadi seseorang yang ditandai dengan timbulnya afektif (perasaan dan reaksi untuk mencapai tujuan). Perubahan energi di dalam diri seseorang tersebut kemudian membentuk suatu aktivitas nyata dalam berbagai bentuk kegiatan. Motivasi terkait erat dengan kebutuhan. Semakin besar kebutuhan seseorang akan sesuatu yang ingin dicapai maka akan semakin kuat motivasi untuk mencapainya. Kebutuhan yang kuat terhadap sesuatu akan mendorong seseorang untuk mencapainya dengan sekuat tenaga. Hanya dengan motivasilah anak didik dapat tergerak hatinya untuk belajar bersama teman-temannya yang lain. Djamarah (dalam Aunurrahman, 2016).

Hasil belajar siswa SMP Negeri 1 Selemadeg masih tergolong kurang karena hanya berkisar pada nilai KKM saja. Hasil belajar adalah suatu tujuan yang ingin dicapai dalam proses belajar. Pengertian hasil belajar tidak dapat dipisahkan dari apa yang terjadi dalam kegiatan belajar baik di kelas, sekolah ataupun di luar sekolah. Hasil belajar adalah segala sesuatu yang menjadi milik siswa akibat dari kegiatan belajar yang dilakukannya (Juliah dalam Jihad, 2013). Menurut Hamalik (dalam Jihad, 2013) hasil-hasil belajar adalah pola-pola 
perbuatan, nilai-nilai, pengertian-pengertian dan sikap-sikap, secara apersepsi dan abilitas. Dari kedua pernyataan di atas dapat disimpulkan bahwa pengertian hasil belajar adalah perubahan tingkah laku siswa secara nyata setelah dilakukan proses belajar mengajar yang sesuai dengan tujuan pembelajaran. Salah satu alternatif yang bisa dipakai untuk memecahkan persoalan tersebut adalah dengan mengembangkan media pembelajaran berbasis SIG dalam pembelajaran IPS. Sehubungan dengan itu dilakukan penelitian dengan fokus pada pemanfaatan media SIG untuk meningkatkan motivasi dan hasil belajar yang dilakukan pada siswa kelas VII SMP Negeri 1 Selemadeg tahun pelajaran 2017/2018.

Rumusan masalah dalam penelitian ini adalah: (1) Bagaimanakah motivasi belajar siswa setelah pemanfaatan media pembelajaran SIG sebagai media pembelajaran IPS kelas VII SMP Negeri 1 Selemadeg ?. Bagaimanakah hasil belajar siswa setelah pemanfaatan media pembelajaran SIG sebagai media pembelajaran IPS kelas VII SMP Negeri 1 Selemadeg ?.

Penelitian ini bertujuan untuk mendapatkan data empiris tentang motivasi dan hasil belajar siswa dengan menggunakan media SIG. Secara khusus tujuan penelitian ini adalah sebagai berikut: (1) mengkaji peningkatan motivasi belajar peserta didik dengan menggunakan aplikasi SIG sebagai media pembelajaran pada mata pelajaran IPS,kelas VII SMP Negeri 1 Selemadeg. (2) menganalisis peningkatan hasil belajar peserta didik dengan menggunakan aplikasi SIG sebagai media pembelajaran pada mata pelajaran IPS,kelas VII SMP Negeri 1 Selemadeg.

\section{METODE PENELITIAN}

Rancangan penelitian ini mengunakan pendekatan eksperimen dengan menggunakan Quasi Experimental Design yaitu The Posttest-only Control Group Design. Dalam rancangan ini subyek yang diambil dari populasi dikelompokkan menjadi dua yaitu kelompok eksperimen dan kelompok kontrol secara acak. Kelompok eksperimen dikenai perlakuan dengan menggunakan media SIG dan kelompok kontrol dikenai perlakuan dengan menggunakan light projector dalam jangka waktu tertentu, kemudian kedua kelompok dikenai pengukuran yang sama. Penelitian ini dilakukan di SMP Negeri 1 Selemadeg Jalan Serma Arda No 8 , Desa Bajera, Kecamatan Selemadeg, Kabupaten Tabanan.

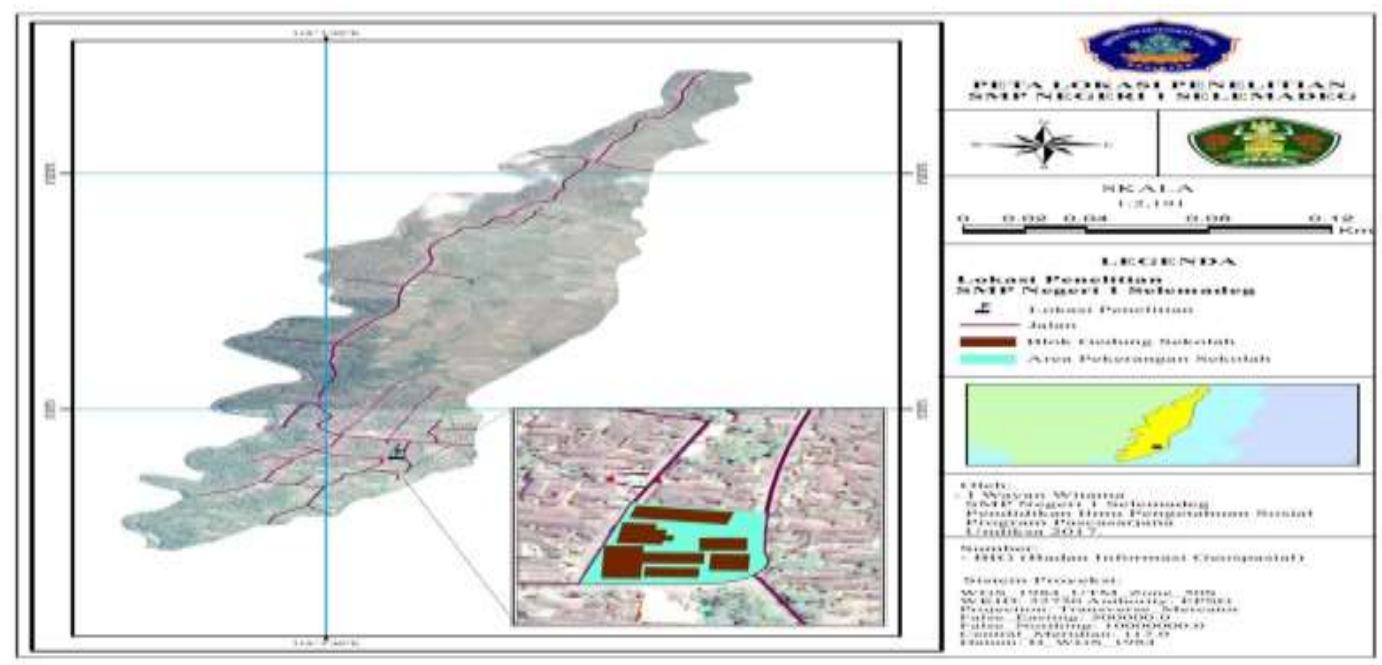

Gambar 1. Peta Lokasi Penelitian 
Populasi dalam penelitian ini adalah semua siswa kelas VII SMP Negeri 1 Selemadeg tahun pelajaran 2017/2018, yang terdiri dari tujuh kelas yaitu kelas VII A, VII B, VII C, VII D, VII E, VII F, dan VII G, dengan jumlah semua kelas adalah 224 orang. Dari populasi yang ada ditetapkan dua kelas sebagai sampel di mana satu kelas sebagai kelompok eksperimen dan satu kelas sebagai kelompok kontrol. Kelas sampel diambil dari kelas-kelas yang memiliki kesetaraan. Untuk mengetahui kesetaraan kelas terlebih dahulu dilakukan uji kesetaraan dengan menggunakan tes formatif siswa. Hasil tes kemudian dianalisis dengan uji- t. Variabel penelitian terdiri dari satu variabel bebas yaitu media pemebelajaran Sistem Informasi Geografis (SIG) dan dua variabel terikat yaitu motivasi dan hasil belajar IPS. Teknik pengumpulan data yang dilakukan dengan cara: (1) Metode dokumentasi digunakan untuk memperoleh data identitas peserta didik dan nilai yang diperoleh dalam pelajaran IPS sebelum penelitian yang dilakukan yang telah dimiliki oleh guru. Hal ini berfungsi untuk mengetahui kondisi awal populasi penelitian kemudian menentukan subyek penelitian. Pada tahap ini data yang diperoleh di lapangan kemudian dianalisis, selanjutnya hasil data disajikan dalam bentuk laporan yang dikonsultasikan dengan dosen pembimbing. (2) Metode observasi digunakan untuk memperoleh data awal tentang motivasi dan hasil belajar siswa sebelum diberikan perlakuan dengan menggunakan media SIG. (3) Metode kuesioner digunakan untuk memperoleh data tentang tanggapan siswa pada saat pembelajaran IPS dengan menggunakan media pembelajaran SIG. Kuesioner yang digunakan adalah kuesioner tertutup, yaitu responden memilih jawaban yang telah disediakan. Data yang diperoleh dipakai untuk mengetahui motivasi belajar siswa. (4) Metode tes digunakan untuk memperoleh informasi tentang hasil belajar siswa dalam ranah kognitif setelah mengikuti pembelajaran dengan media SIG. Tes yang akan digunakan dalam penelitian ini berbentuk tes obyektif. Analisis data yang digunakan dalam penelitian ini adalah uji t independent. Dengan dilakukan uji asumsi (uji prasyarat analisis) terlebih dahulu yang meliputi: uji homogenitas, uji normalitas sebaran data, kemudian dilanjutkan dengan pengujian hipotesis Untuk menginterpretasikan t-test terlebih dahulu harus ditentukan nilai $\alpha$ dan df (degree of freedom). Nilai $\alpha$ dalam penelitian ini yaitu 0,05 , sedangkan nilai df untuk independent sample t-test $\mathrm{df}=\mathrm{N}$-2. Setelah itu nilai dan dibandingkan. Apabila > maka hipotesis ditolak. Apabila < maka hipotesis diterima.

\section{HASIL PENELITIAN DAN PEMBAHASAN}

Dari kedua hipotesis yang diajukan dalam penelitian ini, semua hipotesis dapat diterima. Pengujian kedua hipotesis yang diajukan pada penelitian ini telah menginterprestasikan rincian uji hipotesis dengan pembahasan bahwa motivasi siswa dan hasil belajar IPS yang menggunakan media SIG.

Pertama, Hasil dari perhitungan uji t untuk pengujian hipotesis pertama diperoleh $t_{\text {hitung }}=9,209$, Sig. 0,00 , dan $t_{\text {tabel }}$ untuk taraf signifikansi $5 \%=1,6$. Hal ini berarti $t_{\text {hitung }}>t_{\text {tabel. }}$. Dengan demikian hipotesis nol $\left(\mathrm{H}_{0}\right)$ ditolak dan hipotesis alternatif $\left(\mathrm{H}_{1}\right)$ diterima. Dengan demikian dapat disimpulkan bahwa terdapat peningkatan motivasi belajar siswa dengan menggunakan media SIG pada mata pelajaran IPS di SMP Negeri 1 Selemadeg.

Secara umum rata-rata skor motivasi pada kelompok kontrol diperoleh sebesar 74,8 dengan simpangan baku (standar deviasi) sebesar 4,42. Hasil ini menunjukkan bahwa kecenderungan motivasi pada kelompok kontrol dapat dikategorikan baik, yaitu berada pada rentangan 66,7 - 80 dari skor ideal. Secara umum rata-rata skor motivasi pada kelompok perlakuan diperoleh sebesar 85,6 dengan simpangan baku (standar deviasi) sebesar 4,93. Hasil ini 
menunjukkan bahwa kecenderungan motivasi pada kelompok perlakuan dapat dikategorikan sangat baik, yaitu berada pada rentangan $>80$ dari skor ideal.

Dari perbedaan motivasi belajar pada kedua kelompok siswa terbukti menginterprestasikan tingkat motivasi yang berbeda. Dengan demikian dapat disimpulkan bahwa penggunaan media SIG dapat memberikan kontribusi yang positif terhadap motivasi belajar pada siswa.

Dari hasil uji hipotesis tersebut mengisyaratkan bahwa penggunaan media SIG dapat meningkatkan motivasi belajar pada mata pelajaran IPS. Pembelajaran dengan menggunakan media SIG memberikan kesempatan yang lebih banyak kepada siswa untuk belajar dan memperoleh pemahaman mengenai pengetahuan yang dibutuhkan secara langsung sehingga apa yang dipelajarinya lebih bermakna bagi dirinya.

Hamalik (2012) mengemukakan bahwa pemakaian media pembelajaran dalam proses belajar mengajar dapat membangkitkan keinginan dan minat yang baru, membangkitkan motivasi dan rangsangan kegiatan belajar dan bahkan membawa pengaruh psikologis terhadap siswa. Penggunaan media pembelajaran pada tahap orientasi pembelajaran akan sangat membantu keefektifan pembelajaran dan penyampaian pesan dan isi pelajaran pada saat itu. Secara umum manfaat media dalam pembelajaran adalah memperlancar interaksi guru dan peserta didik, dengan maksud membantu peserta didik belajar secara optimal. Manfaat media pembelajaran dikemukakan oleh Kemp dan Dayton dalam Nuryanto (2012) menyebutkan yaitu proses pembelajaran menjadi lebih menarik, media dapat menyampaikan informasi yang dapat didengar (audio) dan dapat dilihat (visual) sehingga dapat mendeskripsikan prinsip, konsep, proses atau prosedur yang bersifat abstrak dan tidak lengkap menjadi lebih jelas dan lengkap. Dengan demikian siswa akan termotivasi untuk menggali lebih dalam tentang materi IPS.

Hasil penelitian ini relevan dengan penelitian yang dilakukan oleh Nurahman (2016) dalam penelitiannya yang berjudul pengaruh penggunaan media pembelajaran terhadap motivasi belajar siswa kelas XI IPS SMA Laboaratorium. Hasil penelitiannya menunjukkan bahwa penggunaan media pembelajaran berpengaruh terhadap motivasi belajar siswa, pada mata pelajaran akuntansi. Hasil penelitian ini telah diuji dan diterima kebenarannya dengan tingkat kepercayaan 95\%. Hal ini dibuktikan dengan nilai korelasi sebesar 0,750 dan koefisien determinasi sebesar 0,563. Hal ini berarti penggunaan media pembelajaran mempengaruhi motivasi belajar siswa pada mata pelajaran akuntansi sebesar $56,3 \%$

Kedua, Hasil dari perhitungan uji t untuk pengujian hipotesis kedua diperoleh $t_{\text {hitung }}=3,992$, Sig. 0,00 , dan $t_{\text {tabel }}$ untuk taraf signifikansi $5 \%=1,6$. Hal ini berarti $t_{\text {hitung }}>t_{\text {tabel. }}$. Dengan demikian hipotesis nol $\left(H_{0}\right)$ ditolak dan hipotesis alternatif $\left(\mathrm{H}_{1}\right)$ diterima. Dengan demikian dapat disimpulkan bahwa terdapat peningkatan hasil belajar siswa dengan menggunakan media SIG pada mata pelajaran IPS di SMP Negeri 1 Selemadeg.

Secara umum rata-rata skor hasil belajar IPS pada kelompok kontrol diperoleh sebesar 8,3 dengan simpangan baku (standar deviasi) sebesar 4,3. Hasil ini menunjukkan bahwa kecenderungan hasil belajar IPS pada kelompok kontrol dapat dikategorikan cukup baik, yaitu berada pada rentangan 6,3 - 8,7 dari skor ideal. Secara umum rata-rata skor hasil belajar pada kelompok perlakuan diperoleh sebesar 11,9 dengan simpangan baku (standar deviasi) sebesar 2,7. Hasil ini menunjukkan bahwa kecenderungan hasil belajar IPS pada kelompok perlakuan dapat dikategorikan sangat baik, yaitu berada pada rentangan $>11,5$ dari skor ideal. 
Dari perbedaan hasil belajar pada kedua kelompok siswa terbukti menginterprestasikan hasil belajar yang berbeda. Dengan demikian dapat disimpulkan bahwa penggunaan media SIG dapat memberikan kontribusi yang positif terhadap hasil belajar pada siswa khususnya pelajaran IPS.

Hamalik (2012) menyebutkan bahwa pemakaian media pembelajaran selain meningkatkan motivasi juga dapat meningkatkan pemahaman, menyajikan data dengan menarik dan terpercaya, memudahkan penafsiran data dan memadatkan informasi. Levie dan Lents (dalam Arsyad, 2011) mengemukakan bahwa empat fungsi media pembelajaran khususnya media visual yaitu fungsi atensi, fungsi afektif, fungsi kognitif dan fungsi kompensatoris. Yang dimaksud dengan fungsi atensi media visual merupakan inti yaitu menarik dan mengarahkan perhatian siswa untuk berkonsentrasi kepada isi pelajaran yang berkaitan dengan makna visual yang ditampilkan atau menyertai teks materi pelajaran. Fungsi afektif media visual dapat terlihat dari tingkat kenikmatan siswa ketika belajar dengan gambar. Fungsi kognitif media visual terlihat dari temuan penelitian yang mengungkapkan bahwa lambang visual atau gambar memperlancar pencapaian tujuan untuk memahami dan mengingat informasi yang terkandung dalam gambar. Fungsi kompensatoris media pembelajaran terlihat dari hasil penelitian bahwa media visual yang memberikan konteks untuk memahami teks membantu siswa yang lebih dalam mengorganisasikan informasi dalam teks dan mengingat kembali.

Hasil penelitian ini relevan dengan Hariyati (2014) yang berjudul pengaruh pengunaan media pembelajaran terhadap hasil belajar siswa pada mata pelajaran IPS Terpadu di SMP Negeri 12 Palu. Dalam penelitiannya menunjukkan bahwa ada pengaruh yang signifikan antara penggunaan media pembelajaran terhadap hasil belajar siswa dalam pembelajaran IPS Terpadu di SMP 12 Palu dengan tingkat hubungan yang kuat.

\section{PENUTUP}

Berdasarkan hasil pengujian hipotesis dan pembahasan dapat disimpulkan bahwa: (1) terdapat peningkatan motivasi belajar siswa dengan menggunakan media Sistem Informasi Geografis (SIG) pada mata pelajaran IPS SMP Negeri 1 Selemadeg. (2) terdapat peningkatan hasil belajar siswa dengan menggunakan media Sistem Informasi Geografis (SIG) pada mata pelajaran IPS SMP Negeri 1 Selemadeg.

Dari hasil penelitian telah terbukti bahwa ada peningkatan motivasi dan hasil belajar siswa dengan menggunakan media SIG pada mata pelajaran IPS kelas VII SMP Negeri 1 Selemadeg tahun pelajaran 2017/2018. Bercermin dari hasil penelitian ini, maka penggunaan media SIG dapat dipertimbangkan untuk diimplementasikan dalam proses pembelajaran di kelas terutama dalam meningkatkan kemampuan siswa dari ranah kognitif, afektif dan psikomotorik. Media SIG adalah suatu media yang tepat untuk membantu siswa berpartisipasi aktif dalam pembelajaran tentang apa yang mereka pelajari dalam ruang lingkup tema tertentu.

Penggunaan media SIG dalam pelaksanaan pembelajaran akan menghasilkan beberapa nilai lebih dalam hubungannya dengan pengembangan potensi diri siswa dan antisipasi positif dalam upaya pembentukan watak dan karakteristik warga belajar, yaitu: (1) meningkatkan rasa tanggung jawab individu, (2) menumbuhkan ketergantungan yang bersifat positif, (3) memungkinkan terbinanya hubungan yang bersifat terbuka, dan (4) memungkinkan pengembangan keterampilan-keterampilan sosial secara optimal. Berdasarkan kajian tersebut dapat dipertimbangkan penggunaan media SIG dalam pelaksanaan pembelajaran sebagai implikasi dan tindak lanjut dalam mengatasi permasalahan pembelajaran di kelas. 
Media pembelajaran menempati posisi yang sangat strategis dalam rangka mewujudkan proses belajar mengajar secara optimal. Proses belajar yang optimal merupakan salah satu indikator untuk mewujudkan motivasi dan hasil belajar siswa yang optimal pula. Hasil belajar yang optimal juga merupakan salah satu cermin keberhasilan dalam pendidikan. Dalam perkembangan ilmu pengetahuan dan teknologi yang begitu pesat dewasa ini guru dituntut mampu memilih dan menggunakan berbagai jenis media pembelajaran sehingga memudahkan siswa untuk belajar.

Berdasarkan hasil observasi dan wawancara dengan guru IPS di SMP Negeri 1 Selemadeg diperoleh data bahwa guru masih mengalami kendalakendala dalam pemanfaatan media pembelajaran SIG. Dalam proses belajar mengajar guru belum menggunakan media pembelajaran yang sesuai dengan materi pelajaran. Hal ini disebabkan karena guru belum memiliki kemampuan untuk mempraktekkan pengoperasian SIG melalui media komputer. Sarana sekolah yang dapat dijadikan media pembelajaran IPS pun masih kurang. Kumputer yang ada di sekolah belum memiliki aplikasi SIG, guru juga tidak pernah menggunakan laboratorium komputer untuk kegiatan pembelajaran. Media peta yang ada di sekolah juga hanya peta-peta umum saja seperti Peta Indonesia, Peta Dunia, Peta Asia Tenggara, Peta Provinsi dan beberapa peta tematik. Selain itu sarana penunjang untuk aplikasi SIG seperti GPS, digitizer, scanner, Central Prosesing Unit (CPU), Hard-disk, komputer atau laptop belum tersedia secara maksimal. Akibat minimnya media pembelajaran yang ada di sekolah mengakibatkan pelaksanaan pembelajaran kurang maksimal. Guru lebih memilih untuk menggunakan buku paket dan menyampaikan materi dengan berceramah, tugas dan tanya jawab saja.

Beberapa saran yang dikemukakan terkait dengan hasil penelitian dan simpulan di atas yaitu :

(1) Hasil penelitian menunjukkan bahwa siswa yang belajar menggunakan media SIG secara signifikan memiliki motivasi dan hasil belajar yang tinggi. Melalui pemanfaatan media SIG siswa memperoleh pengalaman belajar yang lebih menarik, menyenangkan, dan mempunyai pengalaman nyata tentang konsep keruangan. Untuk itu disarankan agar siswa mempraktekkan pengalaman belajar ini dalam kehidupan sehari-hari. (2) Disarankan kepada guru khususnya guru yang membidangi mata pelajaran IPS agar dapat mengembangkan media pembelajaran SIG dengan mempelajari materi SIG baik teori maupun praktek melalui berbagai pelatihan sehingga mempermudah dalam mentransfer materi IPS kepada siswa sehingga diharapkan motivasi dan hasil belajar juga meningkat. (3) Disarankan kepada kepala sekolah dan jajarannya untuk dapat memberikan sumbangan pemikiran dan mempertimbangkan serta mensosialisasikan media pembelajaran SIG sebagai media pembelajaran alternatif, dan meningkatkan pemahaman guru tentang pentingnya media SIG . Sosialisasi dan pengenalan terhadap media pembelajaran ini dapat dilakukan melalui seminar, pertemuan MGMP atau pelatihan lainnya yang dapat diprakarsai di bawah bimbingan dan koordinasi Kepala Sekolah. Sekolah hendaknya berupaya untuk mengadakan fasilitas-fasilitas sekolah seperti software dan hardware SIG yang dapat menunjang kegiatan pembelajaran IPS. (4) Disarankan kepada peneliti lain untuk dapat melakukan penelitian lebih lanjut mengenai berbagai bentuk media pembelajaran inovatif dan pengaplikasiannya di lapangan dalam upaya meningkatkan kualitas lulusan. 


\section{DAFTAR RUJUKAN}

Arsyad, Azhar. 2011. Media Pembelajaran. Jakarta: PT Raja Gralindo Persada.

Aunurrahman. 2016. Belajar dan Pembelajaran. Bandung : Alfabeta.

Bovee. Courland. 1997. Business Communication Today. Prentice Hall: New York.

Burrough, P. A. 1986. Principles Of Geographical In formation System For Land Resources Assement. Buttler and Tanner Ltd, Frome and London. Great Britain.

Dantes, Nyoman. 2011. Desain Eksperimen dan Analisis Data. Singaraja : Undiksha Press.

Hamalik,Oemar. 2012. Manajemen Pengembangan Kurikulum. Bandung : Remaja Rosdakarya.

Haryati. 2014. "Pengaruh Penggunaan Media Pembelajaran Terhadap Hasil Belajar Siswa pada Mata Pelajaran IPS Terpadu di SMP Negeri 12 Palu" jurnal.untad.ac.id > jurnal > article > view (diakses tanggal 28 Desember 2007).

Jihad, Asep dan Abdul Haris. 2013. Evaluasi Pembelajaran. Yogyakarta : Multi Pressindo.

Kosasih, H. Djahri, 1994. Buku Pedoman Guru Pengajaran IPS. Jakarta: Departemen $\mathrm{P}$ dan $\mathrm{K}$

Nurahman, Ahmad. 2016. " Pengaruh Penggunaan Media Pembelajaran Terhadap Motivasi Belajar Siswa Kelas XI SMA Laboratorium (Percontohan) Universitas Pendidikan Indonesia" repository. upi. edu> S_PEA_1003174_C... (Diakses tanggal 28 Desember 2017)

Nuryanto, Apri. 2012. Materi Media Pembelajaran. Yogyakarta: UNY

Suhana, Cucu. 2004. Konsep Strategi Pembelajaran. Bandung : Refika Aditama

Suwarma, AL.Mucthar, 1991. Pengembangan Penelitian Tindakan Kelas. Yogyakarta: Lembaga Penelitian IKIP Yogyakarta. 